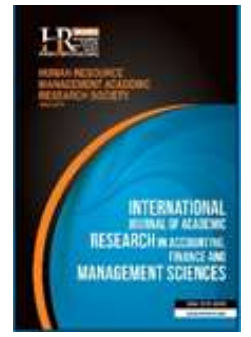

International Journal of Academic Research in Accounting, Finance and Management Sciences

Vol. 10, No.1, January 2020, pp. 239-249

E-ISSN: 2225-8329, P-ISSN: 2308-0337

(C) 2020 HRMARS

www.hrmars.com

To cite this article: Adeniyi, A. J., Marsidi, A., Babatunji, A. S. (2020). Capital Structure and Commercial Banks Performance in Nigeria, International Journal of Academic Research in Accounting, Finance and Management Sciences 10 (1): 239-249

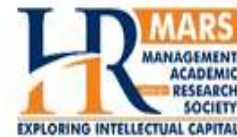

\title{
Capital Structure and Commercial Banks Performance in Nigeria
}

\author{
Akindele Jamiu Adeniyi ${ }^{1}$, Asri Marsidi ${ }^{2}$, Adedeji Samuel Babatunji ${ }^{3}$ \\ ${ }^{1,2}$ Faculty of Economics and Business, Universiti Malaysia Sarawak, \\ ${ }^{1}$ E-mail: jamiuakins307@gmail.com, 22E-mail: maasri@unimas.my \\ ${ }^{3}$ Faculty of Economics and Management, Universiti Putra Malaysia, ${ }^{3}$ E-mail: samtunji2014@gmail.com

\begin{abstract}
Decision relating to capital structure is of great important to an organization as capital performs several indispensable functions in the operations of banks, among which are to mitigate against risk and fragility, maintenance of public confidence as well as enhancing deposits mobilization and efficiency. It is imperative for managers to choose an appropriate financing mix which is a key decision for the growth and going concern of any financial institutions. This study used profit after tax and earnings per share as a measure of performance and employed panel regression technique to analyse data collected from a sample of fourteen quoted commercial banks between 2009 to 2016. The result shows a significant relationship between debt and profitability of commercial banks in Nigeria. The study concludes that debt can be significantly influenced by liquidity and shareholders' wealth. Consequently, the study recommend that commercial bank managers should not depend on debt capital as a source of financing the organization capital structure but rather use retained earnings of the business and consider debt as the least alternatives.
\end{abstract} \\ Key words \\ Capital Structure, Commercial Banks, Debt, Financial Performance, Nigeria \\ Received: 28 Mar $2020 \quad$ c) The Authors 2020 \\ Revised: 07 Apr 2020 Published by Human Resource Management Academic Research Society (www.hrmars.com) \\ Accepted: $12 \mathrm{Apr} 2020$ This article is published under the Creative Commons Attribution (CC BY 4.0) license. Anyone may \\ reproduce, distribute, translate and create derivative works of this article (for both commercial and \\ non-commercial purposes), subject to full attribution to the original publication and authors. The full \\ terms of this license may be seen at: http://creativecommons.org/licences/by/4.0/legalcode
}

\section{Introduction}

The banking institutions are financial institutions that play the intermediation role between the surplus and deficit sectors in any economy. Banking sector enhances the flow of funds for productive purposes. It is possible that the amount given as loan is less than the total sum paid by the deficit sector and in that case, the banking institution is supposed to payback the surplus sector from the equity of the banks (Al-Mutairi \& Naser, 2015). The banking sector is of great interest to investors because banks are primarily concerned with liquidity and much more committed to solvency and their liabilities are majorly in short-term which are payable on demand with few fixed costs and low operating leverage compare to other counterpart sectors of the economy like telecommunication and manufacturing. Therefore, financing in bank is of paramount importance to both the management and providers of funds because if a wrong mix of finance is used, it will seriously affect the performance and the going concern of such bank.

Capital structure explains the owners' rights and interests of creditors' proportional relationship; it indicates the ratio between the corporate structure and the various sources of financing, and their mutual combinations Bauer (2004). The capital structure theory is an essential theory in finance as it addresses sources of finance available to business organizations wishing to raise funds to finance their operations. These includes equity sales, retained earnings, bonds, bank loans, accounts payable and line of credit 
(Diamond,1984; Ross, Schwaiger \& Winkler, 2003) and possibly few other interest-bearing debts. Decision relating to capital structure is of great important for any organization since there is need to maximize return to the various stakeholders in the business and such decision has a considerable influence on the firms' capability to deal with competitive environment (Awunyo-Vitor \& Badu, 2012).

Capital structure decision is a vital decision in organization as it has a direct effect on a decision relating to profitability of any business enterprise. Thus, capital performs several indispensable functions in the operations of banks, among which are to mitigate against risk and fragility, maintenance of public confidence as well as enhancing deposits mobilization and efficiency. The Nigerian banking sector is regulated by the Central Bank of Nigeria (CBN) which stipulated the minimum capital requirement for commercial banks in the country to N25 Billion. To achieve this, banks needed to mix both debt and equity strategically to attain capital structure at an optimal level Aremu et al. (2013). Among the key issue facing bank managers nowadays is to determine the right mix of debt and equity to attain optimal capital structure level for the business to reduce the company's cost of capital and consequently enhances return on investment to the shareholders.

Appreciable efforts have been made on the effect of capital structure on organization performance both industry-wise and country-wise in the last few decades. Studies from countries like Jordan, UK, Malaysia, Sri Lanka and Tehran dominate this body of knowledge such as the studies conducted by Zeitun \& Tian (2007), Eriotis et al. (2007) Ong \& Teh (2011), Nireh (2012), Khalaf (2013) with very few empirical studies emerging from Nigeria such as the study conducted by Akeem et al. (2014) and Akinyomi (2013). However, there is scarce evidence from prior literatures that empirically examine the effect of capital structure on performance of commercial banks in Nigeria. Therefore, our study will be a pioneer study which is non-existent in Nigerian literature in respect of commercial banks. This study is significant in the sense that it will be of immense benefit not only to the companies in the Nigerian banking sector, but also to the Nigerian economy as well as to improving the structure of capital and enhancing value driven performance for survival of banking industry. Hence, it is imperative for banking sector in Nigeria to put into consideration the structure of capital activities to achieve organization objective.

\subsection{Objectives of the Study}

The study of firm performance has been an inexhaustible subject that has drawn the attention of several researchers. It has been known from the literatures that the performance of corporate organizations is the major concerns of all the stakeholders in the business. In view of this, financial performance is the most important and reliable indicator as it gives a broad indicator of the ability of companies to raise their income level Ahmed et al. (2011).

The main objectives of this study are:

i. To evaluate the impact of capital structure on the performance of commercial banks in Nigeria,

ii. To examine the effect of capital structure on the liquidity management of commercial banks in Nigeria, and

iii. To determine the effect of capital adequacy on performance of commercial banks in Nigeria.

\subsection{Research Questions}

To achieve the research objectives, the following research questions were developed and shall be answered during research study:

i. How much effect does the capital structure have on the profitability of commercial banks in Nigeria?

ii. How does capital structure impact on liquidity management in Nigerian commercial banks?

iii. How much effect does the capital adequacy have on performance of commercial banks in Nigeria?

\section{Literature review}

\subsection{Conceptual Issues}

Capital structure refers to the owner of the rights and interests of creditors' proportional relationship; it indicates the ratio between the corporate structure and the various sources of financing, 
and their mutual combinations Bauer (2004). Rajan and Zingales (1995) opined that capital structure, in financial terms, means how a firm finances its assets through the combination of equity and debt. A company can only employ equity leading to an unlevered firm, whereas a mixture of equity and debt entails a levered firm while hybrid capital contain features of both debt and equity. According to Van Horne and Wachowicz (2008) debts, preferred stock and common stock are components of capital structure. Meanwhile, capital structure of banks is mostly in form of debt than equity.

\subsection{Determinants of Capital Structure}

Mathanika and Pavithira (2015) observed that capital structure of the firm is a function of both internal and external factors. The internal factors are the bank specific factors affecting capital structure, such as profitability, growth rate, size of a firm, nature of a firm, period of finance and taxes while the external factors are the macro-economic variables affecting the industry or economy in general which includes bond market, gross domestic product and interest rate. The financial requirement of growing firm is usually very high as fund generated internally may not be adequately enough to finance their business and rather need to rely on external debt, while the firm with high rate of return on investment make use of internal sources Athula et al. (2011). The size of a company determines the level of diversification of the company and influence how such a company can easily access the stock exchange for debt issuance and pay low interest rate on debt capital.

The period of finance is a key factor among the determinants of capital structure. Finance required for a short term will mostly be sourced through debts or fixed deposits while finance for a longer period will be sourced from equity. Athula et al. (2011) argue that corporate tax has both direct and indirect bearing on capital structure decisions, interest is paid on debt prior to the calculation of the corporate income tax and dividends are declared after the tax calculation. A firm with a high chance of having zero tax rates is less likely to finance its business with debt. This is because tax shields can reduce the effective marginal tax rate on deduction of interest while a firm with lower tax yield is most likely to finance its business with equity.

\subsection{Concept of Debt Financing}

Debt finance is when an organization borrows money with interest attached to it which will be paid back at a future determinable period. The core feature of debt financing is that the amount borrowed, plus interest, must be paid back to the providers of debt over a given period. Meanwhile, debt financing can be classified into two namely the short-term debt financing and the long-term debt financing. The short-term debt financing is the type of financing where the repayment period is less than a year and is mostly associated with operation of the business such as payroll, inventory and purchasing and supply while in the long-term debt financing, the schedule of debt payment is expanded for more than a year example of such is land and building, equipment and large machinery. Debt financing is a means of financing business enterprise by selling the bonds, mortgages, or loan of the business. These types of instruments are used by large firms to raise capital for their operation or projects. Debenture financing are means by which a firm raise capital without making use of their own assets or give up ownership in their firms. Another characteristic of debt financing is that it frees the other assets of the business to engage in other business activities which will generate capital for the company.

The idea of debt-overhang or underinvestment problem was first put forth by (Myers, 1984). According to Myers (1984) debt-overhang arises when the company debt is so large to the extent that it cannot obtain more debt to finance future investments. This will make it very difficult for company to raise capital for the new project because the proceeds from the new project in most cases may lead to an increase in the value of an existing debt instead of equity.

\subsection{Capital Structure and Performance of Commercial Banks}

The commercial banks perform the major financial intermediaries' functions by mobilizing funds from the surplus unit of the society and channel such fund to the deficit unit in the society (Kipesha \& Moshi, 2014). From the Kipesha and Moshi (2014) point of view, the commercial banks usually thrives on the financial intermediation abilities of financial institutions which give them the right and opportunity to 
lend out money at very high rate of interest while they received money on deposit from customers at a relatively low rates of interest. This also makes the banking activities to perform in accordance with local and international regulation. Dewatripont and Tirole, (1994) posit that bank capital structure which includes deposits from customer contributed to debts of the bank as depositors who may not have any motive to monitor the operations of the bank which limits the disciplinary roles as suggested by the tradeoff theory.

\subsection{Theoretical Framework}

Review of theories behind capital structure provides a foundation for understanding the issue in greater depth. Capital structure stems from the following theories which undoubtedly assisted to understand the key role of capital structure decision in enhancing the performance of banking sector of the economy.

\subsubsection{Pecking Order Theory}

This study is based on the theoretical framework of pecking order theory developed by (Myers \& Majluf, 1984). The theory postulates that asymmetric information increases the cost of financing. Because of information asymmetries between the firm and potential investors, the firm will prefer retained earnings to debt, short-term debt over long-term debt and debt over equity. According to Nakamura et al. (2007), this order assumes that "[...] resources generated internally do not have transaction costs, and issuing new bonds tends to signal positive information about the company, while issuing new shares, on the contrary, tends to signal negative information". Myers and Majluf (1984) suggest that the problem of information asymmetric can be solved if firms did not issue new security but rather use only its retained earnings to support the investment opportunities at its disposal. This presupposes that issuing equity becomes more expensive as asymmetric information insiders and outsiders increases. Priority is then given to the internal fund because it is the easiest fund to obtain. However, the idea of information asymmetry has a great impact on the choice between internal and external source of financing. In line with this assertion, Graham \& Harvey (2001) posit that depending on the aims of firms in respect of its level of debt, firm's use external funds only when internal funds are not adequate. Meanwhile, the decision relating to firm's capital structure is greatly influenced by transaction cost and the transaction costs associated with external financing is higher than the transaction cost associated with internal financing. Hence, the use of internal funds does not attract transaction costs and most preferable.

\subsubsection{Agency Cost Theory}

Agency theory is an essential theory in the field of finance and accounting in the recent years. The theory was first developed by (Berle \& Means, 1932) and improved upon by (Jensen \& Meckling, 1976). This theory acknowledged the fact that debt is the main factor that gives rise to conflict of interest between equity holders (principal) and managers (agent) in an organization. This problem is associated with principal principle relationship. The availability of free cash flow can cause managers to over-invest in projects with negative NPV which will consequently reduce the firm's value. Therefore, the capability of the manager to promote their interests is restricted by the availability of free cash flows. This is valid for debt as in Jensen (1986) and Graham \&Harvey (2001). Jensen and Meckling (1976) posits that "there will always be conflict of interest between owners and managers which may results to an increase in agency costs and because of this there is need to separate ownership from control to achieve optimal capital structure". Jensen \& Meckling (1976) further stress that the probability distribution of cash flows provided by the firm is not independent of its ownership structure and that this fact may be used to explain optimal capital structure. Hence, the scholars conclude that, given increasing agency costs with both the equity-holders and debt holders, the optimal capital structure can be attained by combining the outside debt and equity to reduce the agency costs.

\subsection{Empirical Review}

Zeitun \&Tian (2007) employed data from a sample of 167 companies from Jordan to examine the impact of capital structure on corporate performance for fourteen-year period from 1989 to 2003. Using 
correlations matrix and panel data models, the study confirmed a negative and significant relationship between capital structure and corporate performance. Athula et al. (2011) used data from a sample of 155 companies from Sri Lankan to examine the impact of capital structure on corporate performance for sevenyear period from 2002 to 2008. Using panel data and regression models as estimation techniques, the study confirmed a negative and significant relationship between capital structure and corporate performance of companies in Sri Lanka. Ong and Teh (2011) used data from a sample of 49 construction companies from Malaysian to carry out study on capital structure and firm's performance of Malaysian construction firms for four-year period from 2005 to 2008. The regression analysis confirmed a relationship between capital structure and corporate performance.

Ali et al. (2012) carried out a study on effect of capital structure on the performance of companies in the petroleum sector of Pakistan for ten years period from 2001 to 2010. The study employed panel data of 12 randomly selected firms. Using regression analysis as estimation techniques, the study confirmed a positive and significant relationship between the capital structure and performance of the petroleum industries in Pakistan. Awunyo-Vitor \& Badu (2012) investigated the relationship between capital structure and performance of listed bank in Ghana. The study used a sample of seven banks listed on Ghana Stock Exchange for the period of eleven years from 2000 to 2010. The study applied panel regression analysis as its estimation technique and results of the study show an inverse relationship between capital structure and banks performance.

Boroujeni et al. (2013) investigated the effect of capital structure and ownership structure on firm's performance of 123 Iranian firms for the period of 8 years from 2001 to 2008. Using rate of return on assets as a measure of firm's performance, the evidence of the findings showed that capital structure and ownership structure have a positive impact on the performance of companies listed on TSE. Kipesha \& Moshi (2014) used the data from sample of 38 banks in Tanzania to examine the relationship between capital structure and bank performance for five years period from 2007 to 2011 . The study employed panel data analysis and the finding revealed that Tanzanian banks use more debts to finance their business than equity.

Akeem et al. (2014) examined the effect of capital structure on firm's performance of ten quoted non-financial companies in the Nigerian stock market for ten-year period 2003 to 2012. Data used for the study were collected from annual report of listed Nigerian companies. The study applied descriptive statistics, correlation and regression analysis as its estimation techniques and the evidence of the findings revealed a negative relationship between capital structure and firm performance. Akinyomi (2013) investigated the relationship between capital structure and performance of manufacturing companies in Nigeria. The study employed panel data of five-year period from 2007 to 2011 for three food and beverages manufacturing companies in Nigeria. By using correlation analysis model, the evidence of the findings showed a negative relationship between capital structure and firm performance.

Getahun (2016) investigated the effect of capital structure on the financial performance of insurance companies in Ethiopia for the period of 10 years from 2004 to 2013. The study employed regression analysis model as an estimation technique and the findings revealed that firm leverage, size, tangibility, and business risk have significant effect on performance of insurance companies in Ethiopia.

\section{Methodology of research}

\subsection{Research Design}

Various equations were estimated using balanced panel data technique for the period 2009-2016, while E-views 7 statistical software version was used to analyze the data. The use of panel regression analysis is appropriate because the data for the study was collected over time and from fourteen commercial banks.

\subsection{Population of the Study}

The population of the study comprises of all the twenty-one (21) commercial banks quoted on the NSE over the period 2009 to 2016. 


\subsection{Sample and data source}

Sample of 14 commercial bank were purposively selected from the target population with the belief that it will be adequate to carry out a study of this nature. The banks selected have complete data for the duration of the study from 2009 to 2016 and possess the following features: the financial accounting years and the brand names did not change during the period of the study.

\subsection{Model Specification}

In a competitive business environment, it is imperative for managers to choose an optimal capital structure which is a key decision for the growth, stability and going concern of a business enterprise so as to maximize the return on investment to various stake holders in the business and will also have a great impact in any decision relating to the performance of an organization. Following the reviewed literature above, we modeled the research in line with the work of (Kipesha \& Moshi, 2014) which was specified and modified as:

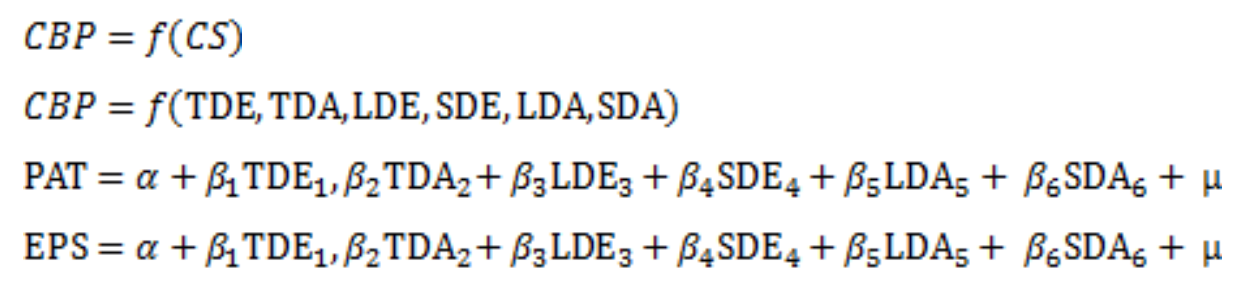

Where:

$\mathrm{CBP}=$ Commercial Bank Performance (PAT, EPS)

$\mathrm{CS}=$ Capital Structure

PAT $=$ Profit after Tax

EPS= Earnings per share

TDE $=$ Total Debt to Equity

TDA $=$ Total Debt to Total Asset

LDE = Long - Term Debt to Equity

SDE = Short - Term Debt to Equity

LDA $=$ Long - Term Debt to Total Asset

SDA $=$ Short - Term Debt to Total Asset

$\mu$ error term

$\alpha$ constant

A priori expectation is that $\beta_{1}, \beta_{2}, \beta_{3}, \beta_{4}, \beta_{5}$ and $\beta_{6}>0$

Decision rule: null hypothesis should be rejected if the prob ( $p$-value) is $<5 \%$ significance level, otherwise it should be accepted.

\section{Analysis}

Table 1. Correlation matrix for multicollinearity test

\begin{tabular}{ccccccccc}
\hline Variables & EPS & LDA & LDE & PAT & SDA & SDE & TDA & TDE \\
\hline EPS & 1 & & & & & & & \\
LDA & -0.04 & 1 & & & & & & \\
LDE & 0.03 & -0.04 & 1 & & & & & \\
PAT & -0.02 & -0.07 & 0.17 & 1 & & & \\
SDA & -0.08 & -0.04 & -0.08 & -0.14 & 1 & & \\
SDE & -0.11 & -0.02 & -0.08 & -0.16 & 0.10 & 1 & & \\
TDA & 0.01 & 0.13 & 0.14 & -0.10 & 0.04 & 0.46 & 1 & \\
TDE & 0.14 & 0.20 & -0.11 & -0.31 & -0.11 & 0.51 & 0.44 & 1 \\
\hline
\end{tabular}

Source: Author's Computation (2017)

Multicollinearity (interdependence among independent variables) is a major problem in multiple regression models because it leads to bias estimates of coefficient and thus render the regression result 
unreliable. To examine the existence of multicollinearity, a pair-wise correlation test was conducted in this study. The result of the correlation obtainable in table $i$ indicates that none of the correlation is shown to be strong and constitute problem of multicollinearity as the coefficients of correlation among the independent variables are less than 0.5 . Therefore, there is no multicollinearity among them.

\subsection{Results and Discussions}

Table 2. Results of fixed and random effect regressions for Profit after Tax (PAT)

\begin{tabular}{lcc}
\hline \multicolumn{1}{c}{ VARIABLES } & $(1)$ & $(2)$ \\
& fixed effect model for PAT & random effect model for PAT \\
\hline Long-term debt to total asset (LDA) & $-0.000080^{* * *}$ & $-0.000096^{* * *}$ \\
& $(0.000024)$ & $(0.000026)$ \\
Short-term debt to total asset (SDA) & $0.12^{* * *}$ & $\left(0.097^{* * *}\right.$ \\
& $(0.031)$ & $-0.094^{* * *}$ \\
Total debt to equity (TDE) & $-0.14 * * *$ & $(0.033)$ \\
& $(0.021)$ & $0.62^{* * *}$ \\
Total debt to total asset (TDA) & $0.62^{* * *}$ & $(0.16)$ \\
& $(0.16)$ & $0.075^{*}$ \\
Short-term debt to equity (SDE) & $0.091^{*}$ & $(0.039)$ \\
& $(0.042)$ & $-0.80^{*}$ \\
Long-term debt to equity (LDE) & $-0.82 *$ & $(0.43)$ \\
Constant & $(0.40)$ & $11.3^{* * *}$ \\
& $10.9 * * *$ & $(1.37)$ \\
Observations & $(0.30)$ & 112 \\
R-squared & 112 & 0.4664 \\
Number of cid & 0.475 & 14 \\
\hline
\end{tabular}

Robust standard errors in parentheses note * indicate significant at $1 \%$ level, $* *$ indicate significant at $5 \%$ level and $* * *$ indicate significant at $10 \%$ level.

Source: Author's computation (2017)

\subsection{Interpretation of the regression results for PAT}

From the table 2 above, the result of the models revealed that total debt to equity, long-term debt to equity and long-term debt to assets are negatively related to performance of commercial banks. It means that an increase in these variables will bring about decrease in profit after tax. The results of both models further illustrate that short-term debt to total asset, total debt to total asset are positively related to profit after tax, meaning that an increase in the variables will bring about increase in profit after tax and vice versa. However, the results of both fixed effect and random effect models show that all the variables are statistically significant. Long-term debt to total asset, short-term debt to total asset, total debt to equity, total debt to total asset are significant at $1 \%$ while, short-term debt to equity and long-term debt to equity are significant at $10 \%$ level of significance. By size of the coefficients, the fixed effect model shows that one unit increase in long-term debt to total asset, short-term debt to total asset, total debt to equity, total debt to total asset, short-term debt to equity and long-term debt to equity will result to about $0.000080 \%$, $0.12 \%, 0.14 \%, 0.62 \%, 0.091 \%$ and $0.82 \%$ increase in profit after tax of the commercial banks in Nigeria respectively. The random effect model shows that the increase in the PAT is because of the increase in the independent variables will be $0.000096,0.097,0.094,0.62,0.075$ and 0.80 percent respectively. The $r$ squared of the fixed effect and random effect models are 0.475 and 0.4664 . These indicate that about $47.5 \%$ and $46.64 \%$ of the changes in profit after tax is explained by changes in the independent variables of the two models, respectively. So, the models have good fit. This implies that the explanatory power of the models is high and therefore, the results are valid for policy inferences. This finding is in line with the work of Zeitun \& Tian (2007), Eriotis et al. (2007), Nireh (2012), Khalaf (2013), and Meero (2015). 
Table 3. Results of fixed and random effect regressions for Earnings per Share (EPS)

\begin{tabular}{lcc}
\hline & $(1)$ & $(2)$ \\
VARIABLES & fixed effect model for EPS & random effect model for EPS \\
\hline Long-term debt to total asset (LDA) & $-0.00064^{* * *}$ & $-0.00057^{* * *}$ \\
& $(0.000031)$ & $(0.000038)$ \\
Short-term debt to total asset (SDA) & $0.084^{* * *}$ & $0.038^{* * *}$ \\
& $(0.016)$ & $(0.010)$ \\
Total debt to equity (TDE) & -0.0072 & 0.020 \\
& $(0.025)$ & $(0.029)$ \\
Total debt to total asset (TDA) & -0.22 & -0.14 \\
& $(0.26)$ & $(0.27)$ \\
Short-term debt to equity (SDE) & $-0.072^{*}$ & $-0.092^{* * *}$ \\
& $(0.038)$ & $(0.035)$ \\
Long-term debt to equity (LDE) & $0.50^{*}$ & 0.52 \\
& $(0.28)$ & $(0.33)$ \\
Constant & -0.13 & -0.26 \\
& $(0.26)$ & $(0.46)$ \\
Observations & 112 & 112 \\
R-squared & 0.692 & 0.6631 \\
Number of cid & 14 & 14 \\
\hline
\end{tabular}

Robust standard errors in parentheses note $*$ indicate significant at $1 \%$ level, ${ }^{* *}$ indicate significant at $5 \%$ level and $* * *$ indicate significant at $10 \%$ level.

Source: Author's computation (2017)

From the regression results presented in table 3 above, both models show that long-term debt to total asset, total debt to equity, total debt to total asset and short-term debt to equity are inversely related to EPS while all other variables are positively related to it. However, half of each coefficient is greater than its standard errors, the variables are statistically significant. Similarly, in the random effect model, longterm debt to total asset, short-term debt to total asset and short-term debt to equity, with coefficient $0.00057,0.038$ and -0.092 as well as standard errors $0.000038,0.010$ and 0.035 respectively are the only significant variables. Therefore, long-term debt to total asset, short-term debt to total asset, short-term debt to equity and long-term debt to equity are the only important determinants of the shareholders wealth of commercial banks in Nigeria. In other words, capital structure has enormous effect on the shareholders' wealth of commercial banks in Nigeria. By magnitude, fixed effect model indicates that 0.00064 and 0.072 units decrease in the EPS result from increase in long-term debt to total asset and shortterm debt to equity, respectively. On the other hand, 0.084 and 0.50 increase in EPS resulted from increase in short-term debt to total asset and long-term debt to equity, respectively. Similarly, in the random effect model, a unit increase in the long-term debt to total asset and short-term debt to equity brings about 0.00057 and 0.092 decreases in the EPS, respectively. Conversely, 0.038 increases in EPS results from increase in short-term debt to total asset.

The $\mathrm{R}^{2}$ statistics shows that $69.2 \%$ (for fixed effect model) and $66.31 \%$ (for random effect model) variation in firm's EPS is explained by the changes in the independent variables. This shows that the model is relatively good, and its estimates are valid and consistent for policy inferences. This is consistent with the empirical work of Bevan \& Danbolt (2002), Awunyo-Vitor \& Badu (2012).

Table 4. Results of Hausman test for all the models

\begin{tabular}{lcc}
\hline \multirow{2}{*}{ Model } & \multicolumn{2}{c}{ Hausman test } \\
\cline { 2 - 3 } FIXPAT & Chi-Statistics & P-value \\
RANDOMPAT & 12.81 & 0.0461 \\
FIXEPS & 3.11 & 0.7947 \\
RANDOMEPS & & \\
\hline
\end{tabular}


Source: Author's Computation (2017)

\subsection{Interpretation of Hausman test}

The fixed effect models and random effect models used revealed that it has a good fit and statistically viable. It is necessary to use Hausman test to correlate the fixed effect model and random effect models and subsequently make a choice between the models. Regarding this, the null hypothesis for the Hausman test is that the (fixed or random) effect is not correlated with other regressors (independent variables), a random effect model is better than the fixed effect model, or a random effect model is consistent. If the null hypothesis is rejected, use the fixed effect model apart from that go for the random effect model. Meanwhile, the chi-square statistics of the Hausman test between FIXPAT and RANDOMPAT is 12.81 and the $p$-value is 0.0461 . Since the P-value is less than $5 \%$ level of significance, the null hypothesis is rejected, and the result of the fixed effect models is preferable for the models in which PAT is the dependent variables. Similarly, the chi-square statistics of the Hausman tests for the models (FIXEPS \&RANDOMEPS) in which EPS is the dependent variable is 3.11while the P-value is 0.7947 . Because $p$-values are greater than $5 \%$ level of significance, we therefore not rejected the null hypotheses and the results of the random effect models are preferable for the models in which EPS is the dependent variable. This finding is in line with the study of Zeitun \& Tian (2007).

\section{Conclusions and recommendations}

This study examined the effect of capital structure on the performance of commercial banks in Nigeria using data from 14 financial firms listed on the Nigeria Stock Exchange for the period of eight 8 years (2009 - 2016). The study employed panel data regression to analyze the data and found a significant relationship between debts and profitability of commercial banks in Nigeria. The major conclusions revealed negative and statistically significant relationship between commercial banks' capital structure represented as total debt to equity, long-term debt to equity, long-term debt to assets for PAT and longterm debt to total asset, total debt to equity, total debt to total asset and short-term debt to equity for EPS respectively on their profitability. Positive and significant relationship occurred between capital structure proxy as total debt to total asset, short-term debt to equity, short-term debt to total asset and long-term debt to equity, short-term debt to total asset on their profitability for both PAT and EPS, respectively. The outcome comparatively in support of pecking order and agency cost theory. The major implication of this study is the establishment of relevance of capital structure and financing theories as they relate to commercial banks in Nigeria. The choice of capital structure will have a significant effect on commercial bank. Moreover, the study found that debt can be significantly influenced by liquidity and shareholders' wealth.

Majority of empirical research that analysed the effect of capital structure on organization performance were carried out on non-financial sectors and there are few studies on commercial banks in Nigeria. Thus, the present research fills the gap in the literature and offered evidence, using recent data of capital structure on commercial banks performance. This paper provides evidence that financial theory assists in selecting the financing mix that affect commercial banks performance and are in concordant with the theoretical context demonstrated under the literature review.

Consequentially, the study makes the following recommendations: Firstly, commercial banks in Nigeria either highly geared or lowly geared should always take into consideration the amount incurred on leverage because it is a key determinant of the performance of commercial banks. Lastly, in line with pecking order theory, commercial bank managers should not depend on debt capital as a source of financing the organization capital structure but rather use retained earnings of the business and consider debt as the least alternative. The limitation of this study is that the samples are only focus on commercial banks listed on the Nigeria stock exchange. By and large, there are other parts of financial institutions in the stock market like mortgage bank, microfinance banks and insurance companies. Hence, our conclusion may not represent the result on other financial institutions in Nigeria. Moreover, additional variables like macroeconomic factors and corporate governance structure which are not included in our models should be considered for further research to get a comprehensive result on capital structure and corporate performances. In addition to that, future researcher may consider these findings to include other possible variables and this study can be replicated with different sectors. 


\section{References}

1. Abdullah, A., \& Kamal, N. (2015). Determinants of Capital Structure of Banking Sector in GCC: An empirical investigation. Economic and Financial Review, 5 (2), 59-72. https://doi.org/DOI: 10.18488/ journal.aefr/2015.5.7/102.7.959.972

2. Ahmed, Z., Abdullahi, N. H., M., \& Roslan, S. (2011). Capital structure effect on firm's performance: focusing on consumers and industrial sectors on Malaysian firms. International review of business research papers, 8 (5), 137-155.

3. Akeem, L. B., Edwin, T. K., Kiyanjui, W. K., \& Adisa, M. K. (2014). Effects of Capital Structure on Firm's Performance: Empirical Study of Manufacturing Companies in Nigeria. Journal of Finance and Investment Analysis, 3 (6), 39-57. (print version), 2241-0996(online) Scienpress Ltd, 2014

4. Akinyomi, K. R. (2013). Testing trade-off and pecking order predictions about dividends and debt. The Review of Financial Studies, 5 (2), 1-33.

5. Ali, S. A., Zia, S. A., \& Razi, A. (2012). Impact of Capital Structure on the Profitability of Petroleum Sector in Pakistan. Global Journal of Management and Business Research, 12(22). Retrieved from https://journalofbusiness.org/index.php/GJMBR/article/view/916

6. Al-Mutairi, A., \& Naser, K. (2015). Determinants of capital structure of banking sector in GCC: An empirical investigation. Journal of economic and financial review, vol. 5 (2), 959-972. DOI: 10.18488/journal.aefr/2015.5.7/102.7.959.972

7. Aremu, M. A., Ekpo, I. C., Mustapha, A. M., \& Adedoyin, S. I. (2013). Determinants of Capital Structure in Nigerian Banking Sector, International Journal of Academic Research in Economics and Management Sciences. 2, (4), 27-43. http://dx.doi.org/10.6007/IJAREMS/v2-i4/50

8. Athula, M., Anura, D. Z., Khorshed, K. K., \& Anil, C. (2011). Capital structure and firm's performance in emerging economies: An empirical analysis of Sri Lanka firms. Corporate Ownership \& Control 8/ (4).

9. Awunyo-Vitor, D., \& Badu, J. (2012). Capital Structure and Performance of Listed Banks in Ghana. Global Journal of Human-Social Science Research. 12(5). Retrieved from https://socialscienceresearch.org/index.php/GJHSS/article/view/314

10. Bauer, P (2004). Determinants of Capital Structure: Empirical Evidence from the Czech Republic, Czech Journal of Economics and Finance (Finance a uver) Charles University Prague, Faculty of Social Sciences, 54 (1-2), 2-21. http://journal.fsv.cuni.cz/storage/958_s_2-21.pdf

11. Berle, A. A., \& Means, G. C. (1932). The Modern Corporation and Private Property. New York, Macmillan Co.

12. Boroujeni, H. N., Noroozi, M., Nadem, M., \& Chadegani, A. A. (2013). The effect of ownership structure and corporate governance on working capital. Australian Journal of Basic and Applied Sciences, 7(4): 424-430, 2013 ISSN 1991-8178

13. Dewatripont, M., \& Tirole, J. (1994). The Prudential Regulation of Banks. Available at: www.mitpress.mit.edu/books/prudential-regulation-banks Retrieved on 03/09/2017

14. Diamond, D. W. (1984). Financial Intermediation and Delegated Monitoring. The Review of Economic Studies, 51(3), 447-663. DOI: 10.2307/2297430 https://www.jstor.org/stable/2297430

15. Eriotis, N., Vasiliou, D., \& Ventoura-Neokosmidi, Z. (2007). How firm characteristics affect capital structure: an empirical study. Managerial Finance, 33(5) 321 331. https://doi.org/10.1108/ 03074350710739605

16. Getahun, M. (2016). Capital structure and financial performance of insurance industries in Ethiopia. Global Journal of Management and Business Research: C Finance.16 (4), 45-54. OnlineISSN:22494588 PrintISSN:0975-5853 DOI:10.17406/GJMBR

17. Graham, J. R., \& Harvey, C. R. (2001). The theory and practice of corporate finance: Evidence from the field. Journal of Financial Economics, 60 (2-3), 187-243. http://www.sciencedirect.com/science/ article/pii/S0304-405X(01)00044-7

18. Jensen, M., \& Meckling, W. (1976). Theory of the firm: Managerial behavior, agency costs and ownership structure. Journal of Financial Economics, 2 (3), 305-360. https://doi.org/10.1016/0304405X(76)90026-X 
19. Jensen, M. C. (1986). Agency Costs of Free Cash Flow, Corporate Finance, and Takeovers. American Economic Review 76, 323-329.

20. Khalaf, A. (2013). The Relationship between Capital Structure and Firm Performance: Evidence from Jordan. Journal of Finance and Accounting, 1 (3), 41-45. doi: 10.11648/j.jfa.20130103.11

21. Kipeshi, I. E., \& Moshi, J. C. (2014). Diversification strategy and capital structure of multinational corporations. Journal of Multinational Financial Management, 1 (3) 17-37.

22. Mathanika, T., Vinothini, V. A. G., \& Paviththira, R. (2015). Impact of capital structure on firm value: evidence from listed manufacturing companies on Colombo stock exchange (CSE) In Srilanka. Proceeding of international conference on contemporary management, 4 (3), 24-35.

23. Meero, A. A. (2015), The relationship between capital structure and performance in gulf countries banks: A comparative study between Islamic banks and conventional banks. International Journal of Economics and Finance, 7 (12) 141-154. doi:10.5539/ijef. v7n12p140

24. Myers, S. C. (1984). The capital structure puzzle. The Journal of Finance, 39 (3) 575-592. URL: http://links.jstor.org/sici?sici=00221082\%28198407\%2939\%3A3\%3C575\%3ATCSP\%3E2.0.CO\%3B2-\%23

25. Myers, S. C., \& Majluf, N. S. (1984). Corporate Financing and Investment Decisions when Firms have Information that Investors do not have. Journal of financial economics, 13 (2)187-221. https://doi.org/10.1016/0304-405X(84)90023-0

26. Nakamura, W., Martin, D., Forte, D., Carvalho Filho, A., Costa, A., \& Amaral, A. (2007). Determinantes de estrutura de capital no mercado brasileiro: análise de regressão com painel de dados no período 1999-2003. Revista Contabilidade \& Finanças, 18 (44), 72-85. https://doi.org/10.1590/S151970772007000200007

27. Nireh, J. (2012). Capital structure and its determinants in the UK - a decompositional analysis. Applied Financial analysis, 159-170.

28. Ong, T. S., \& Teh, B. H. (2011). Capital structure and corporate performance of Malaysian construction sector. International Journal of Humanities and Social Science, 1 (2), 28-36. ISSN 2220-8488. ESSN: 2221-0989 http://www.ijhssnet.com/journal/index/24

29. Rajan, R. G., \& Zingales, L. (1995). What do we know about Capital Structure? Some evidence from international data. The Journal of Finance, 1 (5), 1421-1460. https://doi.org/10.1111/j.15406261.1995.tb05184.x

30. Ross, S. A., Westerfield, R. W., \& Jordan, B. D. (2003). Fundamentals of Corporate Finance. (6th ed.). McGraw-Hill Irwin Publications, New York.

31. Van Horne, C. J., \& Wachowicz, J. M. (2008). Fundamentals of Financial Management $\left(13^{\text {th }}\right.$ ed.). Pearson Education Ltd. Ediaburgh Gate Harlow England.

32. Zeitun, R., \& Tian, G. G. (2007). Capital structure and corporate profitability: evidence from Jordan. Australasian Accounting, Business and Financial Journal, 1, (4), 40-53. http://ro.uow.edu.au/aabfj 